\title{
Testing Was Performed
}

National Cancer Institute

\section{Source}

National Cancer Institute. Testing Was Performed. NCI Thesaurus. Code C160289.

An indication that specific tests were performed during the study. 